\title{
Immunohistochemical studies on the progesterone receptor $(P R)$ in the sow uterus during the oestrous cycle and in inseminated sows at oestrus and early pregnancy
}

\author{
S Sukjumlong ${ }^{1}$, A-M Dalin ${ }^{2,4}$, L Sahlin $^{3}$ and E Persson ${ }^{1,4}$ \\ ${ }^{1}$ Department of Anatomy and Physiology, ${ }^{2}$ Division of Comparative Reproduction, Obstetrics and Udder Health, \\ Department of Clinical Science, Faculty of Veterinary Medicine and Animal Science, Swedish University of \\ Agricultural Sciences (SLU), Uppsala, Sweden, ${ }^{3}$ Division for Reproductive Endocrinology, Department of Woman \\ and Child Health, Karolinska Institutet, Stockholm, Sweden and ${ }^{4}$ Centre for Reproductive Biology in Uppsala, \\ Sweden
}

Correspondence should be addressed to E Persson; Email: elisabeth.persson@afys.slu.se

\begin{abstract}
Physiological changes in the sow uterus involve the regulation by progesterone and its receptor proteins (PR). Therefore, the aim of the present study was to investigate the localization of PR during different stages of the oestrous cycle and in inseminated sows during early pregnancy by use of immunohistochemistry. Uterine samples were collected from cyclic and inseminated sows at different stages of the oestrous cycle and early pregnancy. The samples were fixed in $10 \%$ formaldehyde and embedded in paraffin. Immunohistochemistry was done by use of a mouse monoclonal antibody to PR. The highest PR immunostaining in the surface epithelium was observed at oestrus $/ 5-6 \mathrm{~h}$ after artificial insemination (Al) and early dioestrus/70 h after AI. In the glandular epithelium, the highest level of PR was found at oestrus with the lowest at late dioestrus/d 19. Higher levels of PR were observed in inseminated groups compared with cyclic sows. In the myometrium, a high level of PR was found at oestrus, while stromal PR cells were constantly present throughout the oestrous cycle and at different stages of early pregnancy. In conclusion, this study shows that the immunopresence of PR in the sow uterus differed between uterine compartments at the same reproductive stage. Differences were also found for some uterine compartments between cyclic and inseminated/early pregnant sows. The relatively consistent immunostaining of PR in the stroma strengthens a stromal role in the regulation of physiological activities in the sow uterus during the oestrous cycle as well as early pregnancy.

Reproduction (2005) 129 349-359
\end{abstract}

\section{Introduction}

The uterus is influenced by the ovarian steroid hormone progesterone, which induces glandular and stromal differentiation as well as cell proliferation (Graham \& Clarke 1997). A stimulatory effect by progesterone on uterine protein secretion has been shown in pigs in several studies (Adams et al. 1981, Roberts et al. 1987, Vallet et al. 1998). During pregnancy progesterone has an important role in preparations for uterine reception of the early embryos and for the maintenance of pregnancy. The effects of progesterone are mediated by interactions of the hormone with specific intracellular progesterone receptors (PR). The importance of PR was studied in knockout mice and it was shown that the adult female PR mutant displayed significant defects in all reproductive tissues including the uterus (Lydon et al. 1996, Conneely et al. 2001). A recent review described that the absence of PR was associated with uterine release of the luteolytic prostaglandin F2alpha $\left(\mathrm{PGF}_{2 \alpha}\right)$ in cyclic ewes and with the onset of uterine gland differentiation in pregnant ewes (Spencer et al. 2004). In gilts, Geisert et al. (1994) showed by immunohistochemical staining that PR proteins were absent in both surface and glandular epithelia at d 12-18 of the oestrous cycle and of pregnancy. Moreover, Persson et al. (1997), by use of enzyme immunoassay, showed that the levels of PR protein were highest in the non-pregnant gilt endometrium at oestrus and metoestrus and that it was low at d $14-18$ as well as at d 25-30 of pregnancy. However, uterine physiology of gilts may differ from that of sows that have experienced a number of pregnancies. To our knowledge, no studies of PR using immunohistochemistry, have been done on the sow uterus.

Our previous studies on oestrogen receptor alpha (ER $\alpha)$ and proliferative activities in the sow uterus revealed that $\mathrm{ER} \alpha$ may be related to proliferation in the epithelia (Sukjumlong et al. 2003, 2004b). However, physiological 
changes in the uterus should involve regulation via PR as well. As PR can be induced by both oestrogen and progesterone (Ing \& Tornesi 1997), it is implied that many of the reproductive physiological responses attributed to PR may be due to the combined effects of oestrogen and progesterone acting through their respective receptors.

Studies in different species have shown that oestrogen increased the presence of PR while progesterone itself decreased PR in many reproductive tissues (Geisert et al. 1994, Dhaliwal et al. 1997, Ing \& Tornesi 1997, Bouchard 1999). However, these effects may not be similar for all cell types of the uterus. The localization of steroid receptors can differ among specific tissue compartments of the uterus, even at the same plasma steroid level. This has been shown for PR in different species (Lessey et al. 1988, Ohta et al. 1993, Wathes \& Hamon 1993, Geisert et al. 1994, Dhaliwal et al. 1997) as well as for ER $\alpha$ in our previous studies on both cyclic and inseminated/early pregnant sow uteri (Sukjumlong et al. 2003, 2004b).

The aim of the present study was to investigate the localization of the PR, by immunohistochemistry, in the sow uterus during different stages of the oestrous cycle and in inseminated sows at oestrus and during early pregnancy.

\section{Material and Methods}

\section{Experimental animals and management}

The experimental plan was approved by the Ethical Committee for Experimentation with Animals. Thirty-three crossbred sows (Swedish Landrace $\times$ Swedish Yorkshire) were used and the study was performed in two experimental groups of sows: fifteen non-pregnant cyclic sows (experiment A) and eighteen inseminated/early pregnant sows (experiment B). The mean parity numbers of these experimental sow groups were $3.4 \pm 0.7$ and $3.4 \pm 0.6$, respectively. The sows were purchased from a commercial herd and brought to the Department of Obstetrics and Gynaecology directly after weaning. They were kept in individual pens and were fed according to the Swedish breeding stock standard for dry sows (Simonsson 1994). The sows had shown normal reproductive performance before selection to the experiment. After weaning (5 weeks of lactation) careful oestrous detection was done by inspection of vulva reddening and swelling as well as control of standing reflex by help of a boar. The ovulation time was checked by ultrasonography. Before slaughter, blood samples were collected from the external jugular vein for analysis of oestradiol-17ß (Mwanza et al. 2000) and progesterone (Rojkittikhun et al. 1993).

In the inseminated/early pregnant groups of sows (experiment B), all sows were inseminated once at 20-15 h before expected ovulation in their second oestrus after weaning (estimated from results of ultrasound examinations at the first oestrus). At insemination, a semen dose containing $10 \times 10^{9}$ spermatozoa in Beltsville Thawing Solution (BTS; Pursel \& Johnson 1976) from two boars of proven fertility was used (Kaeoket et al. 2002).

\section{Tissue collection}

The cyclic sows (experiment A) were slaughtered at five different stages of the oestrous cycle: at oestrus (d 1, 11.5-17.5 $\mathrm{h}$ after the start of the second standing oestrus after weaning; $n=3$ ), early dioestrus (d 4, 70.5-71 h after ovulation; $n=3$ ), dioestrus (d $11-12 ; n=3)$, late dioestrus (d 17; $n=3$ ) and pro-oestrus (d 19; $n=3$ ). In experiment $B$, the inseminated sows were divided into 5 different groups and slaughtered at oestrus, 5-6h after artificial insemination (Al) (group $1 ; n=4$ ), at $20-25 \mathrm{~h}$ after ovulation (group 2, 36-43 h after $\mathrm{Al} ; n=4$ ), at $70 \mathrm{~h}$ after ovulation (group 3, 83-93 h after $\mathrm{Al} ; n=4$ ), on day 11 (group 4, the first day of standing oestrus = day 1 ; $n=3$ ) and on day 19 (group $5 ; n=3$ ).

Immediately after slaughter, the reproductive organs were examined for normality and tissues were sampled. The uterine samples were collected at the mesometrial side, $20-30 \mathrm{~cm}$ from the tip of the uterine horn and fixed in $10 \%$ formaldehyde for up to 4 days. The samples were embedded in paraffin blocks, cut in $4 \mu \mathrm{m}$ thick sections and placed on Superfrost Plus glass slides (Menzel-Glaser, Freiburg, Germany) before immunohistochemistry was carried out.

\section{Immunohistochemistry}

After the sections were deparaffinized in xylene and graded alcohol, antigen retrieval technique was used in order to enhance the reaction between antigen and antibody by boiling in $0.01 \mathrm{M}$ citric buffer $\mathrm{pH} 6.0,2 \times 5 \mathrm{~min}$ in a microwave at 750 watt. All the immunohistochemical procedures were carried out as described earlier (see Sukjumlong et al. 2003). Briefly, a standard avidin-biotin immunoperoxidase technique (Vectastain ABC kit, Vector Laboratories Inc., USA) was applied to detect the PR proteins. The primary antibody used was a mouse monoclonal antibody to both PR-A and PR-B (PR-2C5, Zymed Laboratories, Inc., San Francisco, USA) at the dilution of $1: 200$. The incubation time for the primary antibody was $1 \mathrm{~h}$ at room temperature. A negative control was obtained by replacing the primary antibody with non-immune serum $\left(\operatorname{lgG}_{2 \mathrm{a}}\right)$ of the same concentration as the primary antibody. In the final step, 3,3'-diaminobenzidine (DAB) (Dakopatts AB, Älvsjö, Sweden), a chromogen, was added to visualize the bound enzyme (brown colour). All sections were counterstained with Mayer's hematoxylin followed by mounting in glycerine-gelatin before investigation. Selected sections were photographed with a Nikon microphot-FXA photomicroscope (Nikon Corporation, Tokyo, Japan).

\section{Classification of positively stained cells}

The evaluations of positively stained cells were carried out as blinded preparation by the same person (S Sukjumlong). The results are presented for the different uterine compartments as follows: surface epithelium, glandular epithelium, subepithelial layer of the connective tissue 
stroma and myometrium. In addition, superficial and deep-laying endometrial glands were evaluated separately since the staining patterns differed between these compartments. In the myometrium, only smooth muscle cells were studied. Blood vessels in both endometrium and myometrium were observed but not evaluated. The results of the immunostaining were evaluated in two ways, by a manual scoring method and by image analysis.

\section{Manual scoring}

The manual scoring of PR positive cells was done by classification into three different levels of intensity: weak, + ; moderate, ++ ; and strong, +++ . Since not all cells stained positively in some compartments of the uterus, i.e. the surface epithelium and the myometrium, the proportion of positive to negative cells was also included for these tissues. The proportions were estimated into four different levels (marked A-D): low proportion $(<30 \%$ of positive cells, A); moderate proportion (30-60\% of positive cells, B); high proportion (60-90\% of positive cells, C) and almost all cells positive (more than $90 \%$, D).

\section{Image analysis}

In order to assess the PR immunostaining more quantitatively in each tissue compartment, a Leica microscope (Cambridge, UK) and Sony video camera (Park Ridge, NJ, USA) connected to a computer using an image analysis system (Leica Imaging System Ltd) was applied. Quantification of the immunostaining was performed on five randomly selected fields in each compartment. In the endometrial stroma, evaluations were done in the subepithelial connective tissue layer in which non-stromal elements (superficial endometrial glands, blood vessels) were interactively removed. Also in other compartments, proper areas were selected and blood vessels were excluded interactively. By using the colour discrimination software, the nuclear staining intensity was divided into three different levels: weak, moderate and strong. However, it is difficult for the system to distinguish a faint background from weak staining in the cell nuclei and therefore, to avoid false positive staining, only moderate to strong intensity was included for the image analysis measurement. The results are presented as mean ratio of total area of positive nuclear staining per total area of cell nuclei.

\section{Statistical analyses}

The statistical analyses were performed only on the image analysis results by using the SAS statistical package (SAS for Windows, Version 6.12, Cary, NC, USA). The stage of oestrous cycle in experiment $\mathrm{A}$ and groups of inseminate$\mathrm{d}$ /early pregnant animals in experiment B were regarded as independent variables. Mean values for each class of the independent variables were compared by using NPAR1WAY (Wilcoxon rank sum test). Spearman rank correlations between plasma levels of oestradiol-17 $\beta$, progesterone, and the ratio of PR-positive cells were performed in each experiment by using CORR procedure. $P$ values $<0.05$ were regarded as statistically significant.

\section{Results}

\section{Plasma hormone levels and pregnancy confirmation}

The results of plasma hormone levels (Fig 1a and 1b) were shown previously by Kaeoket et al. $(2001,2002)$ for cyclic and inseminated sows, respectively. The cyclic sows (experiment A) showed high plasma levels of oestradiol$17 \beta$ at prooestrus and oestrus and a high level of progesterone during dioestrus (Fig. 1a). In the inseminated/ pregnant sows (experiment B) (Fig. 1b), the highest level of plasma oestradiol-17 $\beta$ was found at oestrus (group 1)
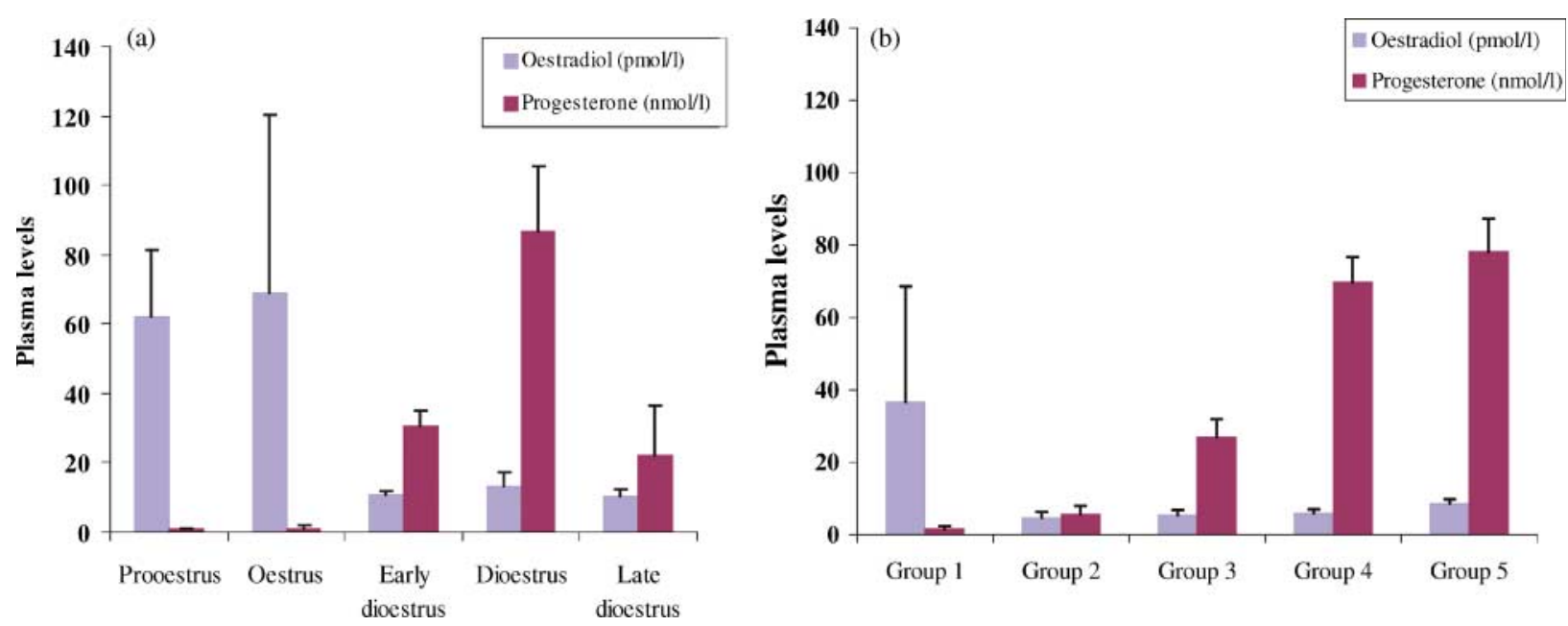

Figure 1 Plasma levels of oestradiol- $17 \beta$ and progesterone (mean \pm s.D.) in sows at different oestrous cycle stages (1a) and in inseminated sows (1b) at oestrous, 5-6 h after $\mathrm{Al}$ (group 1); 20-25 h after ovulation (group 2); $70 \mathrm{~h}$ after ovulation (group 3); $\mathrm{d} 11$ (day $1=$ first day of standing oestrous) (group 4) and d 19 (group 5). 
while the plasma progesterone levels were high at $\mathrm{d} 11$ and d 19 of early pregnancy (groups 4 and 5) (Fig. 1b).

In experiment $\mathrm{B}$, the sows slaughtered before ovulation (group 1) had spermatozoa in the uterus, utero-tubal junction, isthmus and ampulla. All sows slaughtered after ovulation in experiment B were pregnant (groups 2-5) as embryos were observed (Kaeoket et al. 2002).

\section{Immunohistochemistry of PR}

Positive immunohistochemical staining was exclusively found in the nuclei of all uterine cell types and no cytoplasmic staining was observed (Figs 2 and 3). Negative controls showed no staining (Figs $2 f$ and $2 k$ ). The manual scoring and image analysis results are shown according to different tissue compartments in Table 1 for cyclic sows (experiment A) and in Table 2 for inseminated/early pregnant sows (experiment B). For the blood vessels in both endometrium and myometrium, positive cells were rarely observed and therefore not quantified.

\section{Surface epithelium}

\section{Non-pregnant cyclic sows (Table 1) (Fig. 2)}

The most prominent intensities $(++/+++)$ as well as a high proportion of PR-positive cells was found at oestrus and early dioestrus while weak immunostaining and a low proportion was observed at the other stages. The results of image analysis showed that the mean ratio of PR-positive cells was significantly higher at oestrus and early dioestrus compared with other stages $(P<0.001)$.

\section{Inseminated/early pregnant sows (Table 2) (Fig. 3)}

The strongest intensity $(++/+++)$ and a high proportion (D) of PR-positive cells was observed at $70 \mathrm{~h}$ after ovulation (group 3). At oestrus and 20-25 h after ovulation, the staining intensity was weak to moderate while weak staining as well as a low proportion was found at $\mathrm{d} 11$ and d 19 (groups 4 and 5). The results from image analysis showed that the mean ratios of PR-positive cells were higher at oestrus and at $70 \mathrm{~h}$ after ovulation (groups 1 and 3) compared with the other groups (groups 2, 4 and 5) $(P<0.001)$.

\section{Glandular epithelium}

\section{Non-pregnant cyclic sows (Table 1) (Fig. 2)}

The manual scoring results showed that almost all glandular cells were PR-positive except for superficial glands at prooestrus and oestrus. The staining intensity in superficial glands was weak and/or moderate at all stages. The strongest intensity $(++/+++)$ was observed in the deep glands at oestrus.

For the image analysis results, the highest mean ratio of PR-positive nuclei was found at oestrus in both layers of glandular epithelium compared with the other stages $(P<0.001)$.

\section{Inseminated/early pregnant sows (Table 2) (Fig. 3)}

In the groups studied, almost all cells were PR-positive (D) but with different intensities. In the superficial glands, the strongest intensity $(++)$ was observed at $70 \mathrm{~h}$ after ovulation (group 3) while weak staining was observed at 20$25 \mathrm{~h}$ after ovulation (group 2) and at d 19 (group 5). Strongest intensity $(++/+++)$ in the deep laying glands was found at oestrus and 20-25 h after ovulation (groups 1 and 2). At $d 19$ (group 5) the staining intensity of most glandular epithelial cells was weak.

The image analysis showed that the highest mean ratio of PR-positive cells was found at oestrus (group 1) $(P<0.001)$ while the lowest mean ratio of positive cells was found at $\mathrm{d} 19$ in both layers of glands compared with all other groups $(P<0.001)$.

\section{Connective tissue (subepithelial layer)}

Non-pregnant cyclic sows (Table 1) (Fig. 2)

Almost all cells were PR-positive at all stages of the oestrous cycle. However, the intensities differed, being strong at oestrus, strong/moderate at prooestrus and early dioestrus, and moderate at dioestrus and late dioestrus. For the image analysis results, the highest ratio of PR-positive cells was found at oestrus $(P<0.001)$ while the lowest ratio of positive cells was found at dioestrus which was significantly different to all other groups $(P<0.001)$.

\section{Inseminated/early pregnant sows (Table 2) (Fig. 3)}

The staining intensity of PR-positive cells was moderate/ strong at oestrus and at 20-25 h after ovulation (groups 1 and 2) but moderate or moderate/weak in the other groups. The image anaysis results showed higher ratios of PR-positive cells at oestrus (group 1) compared with other groups $(P<0.001)$.

\section{Myometrium}

Non-pregnant cyclic sows (Table 1) (Fig. 2)

The manual scoring method showed that almost all myometrial cells were PR-positive at all stages. The intensity of positive staining in the myometrium was moderate/ strong at prooestrus and oestrus. At the other stages, the staining intensity was weak to moderate. The results from image analysis showed that the mean ratio of PR-positive cells was significantly higher at prooestrus and oestrus while low ratios of positive cells were found at the other stages $(P<0.001)$.

\section{Inseminated/early pregnant sows (Table 2) (Fig. 3)}

Almost all cells were PR-positive in all groups and moderate/strong intensity was found at oestrus and $20-25 \mathrm{~h}$ after 

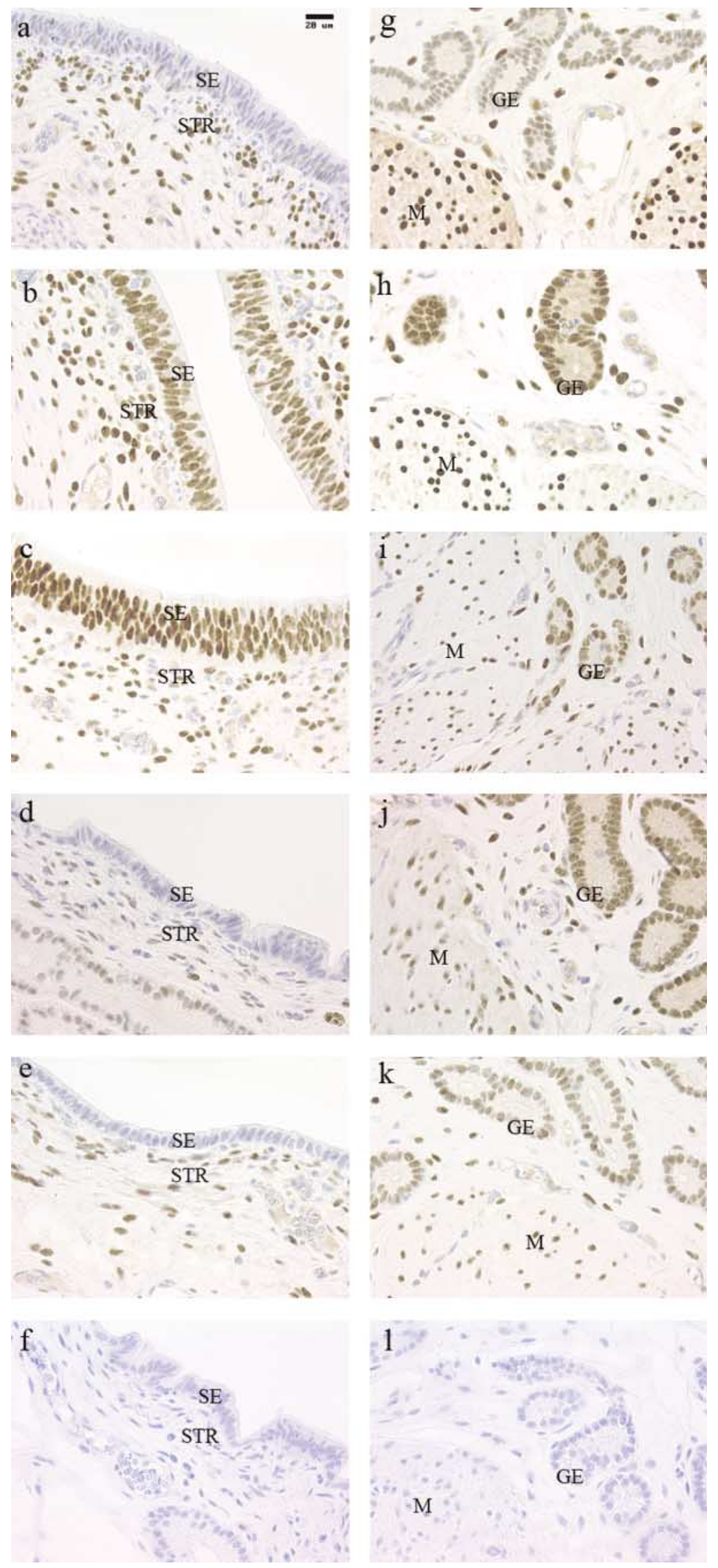

www.reproduction-online.org
Figure 2 Immunohistochemical localization of PR in different tissue compartments of the sow uterus: $a-f$, surface epithelium (SE) and subepithelial layer of the connective tissue (STR); g-I, glandular epithelium (GE) and myometrium (M). Stages of the oestrous cycle: prooestrous, d 19 (a and g); oestrous, d 1 (b and h); early dioestrous, d 4 (c and i); dioestrous, $d$ 11-12 ( $\mathrm{d}$ and $\mathrm{j}$ ); late dioestrous, $\mathrm{d} 17$ (e and k); negative control, ( $\mathrm{f}$ and $\mathrm{I}$ ). 

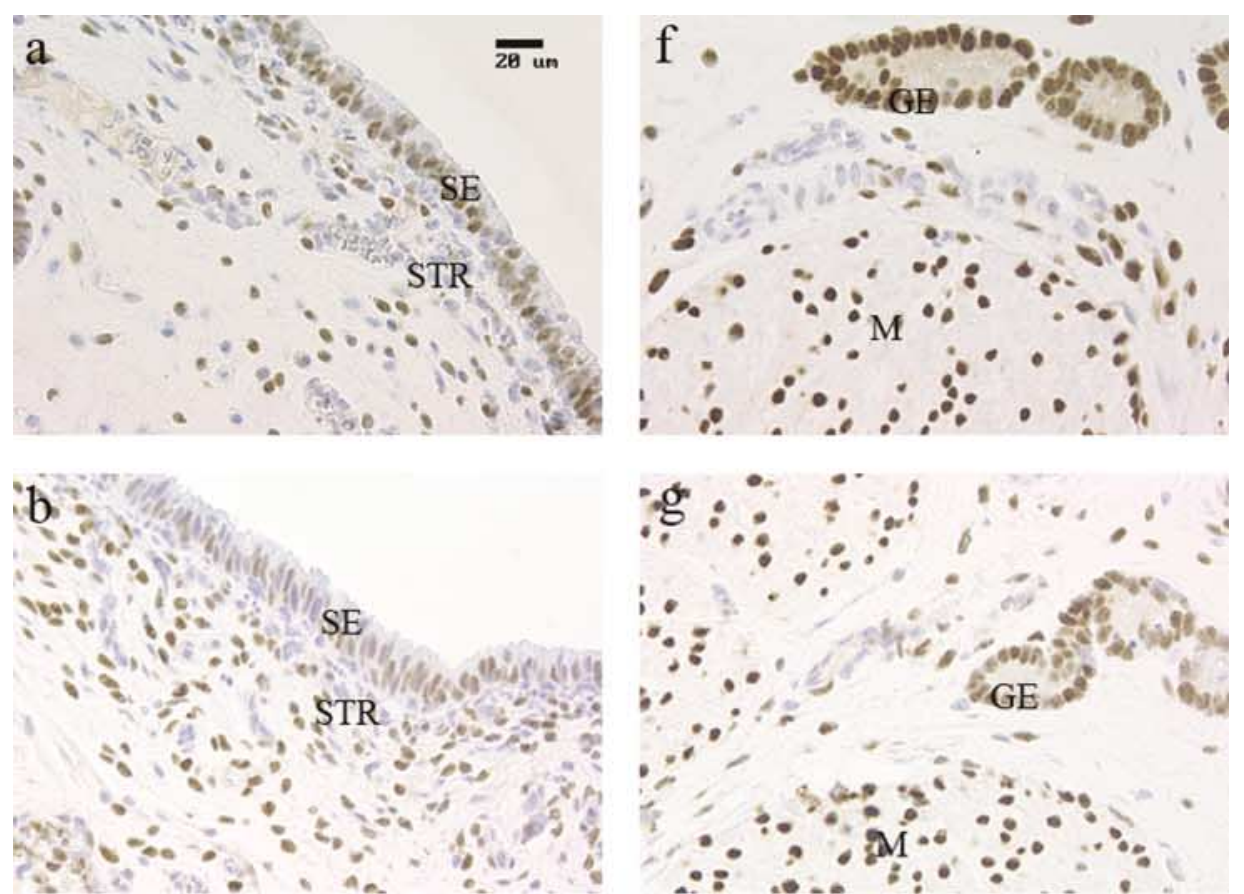

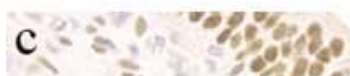
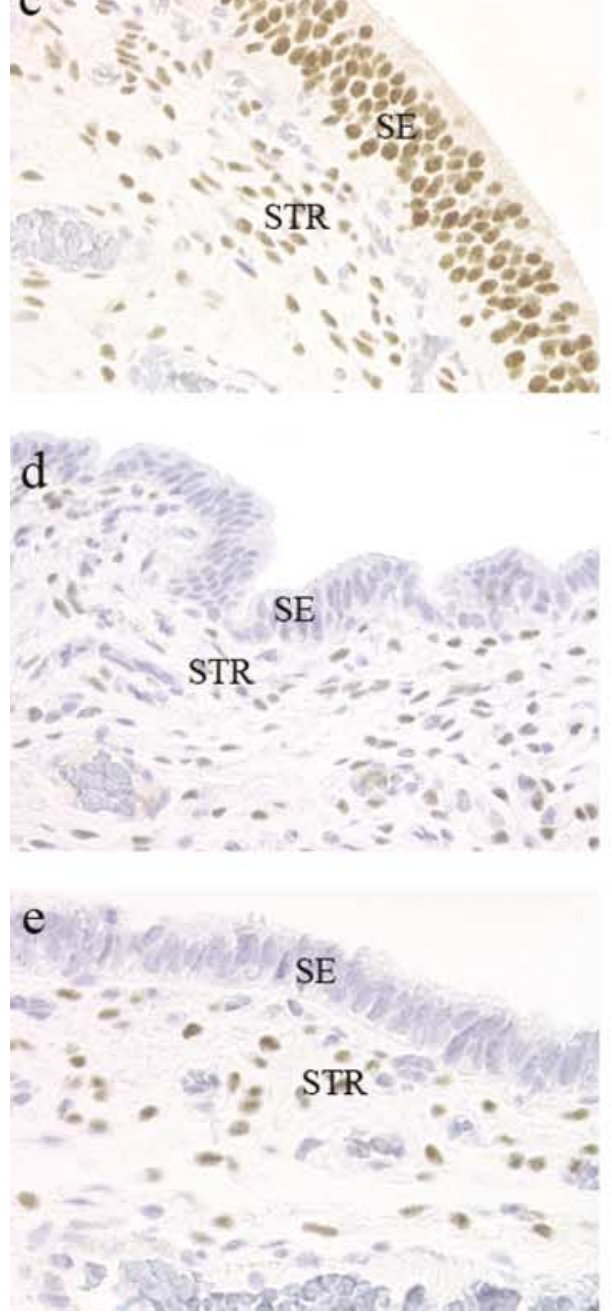
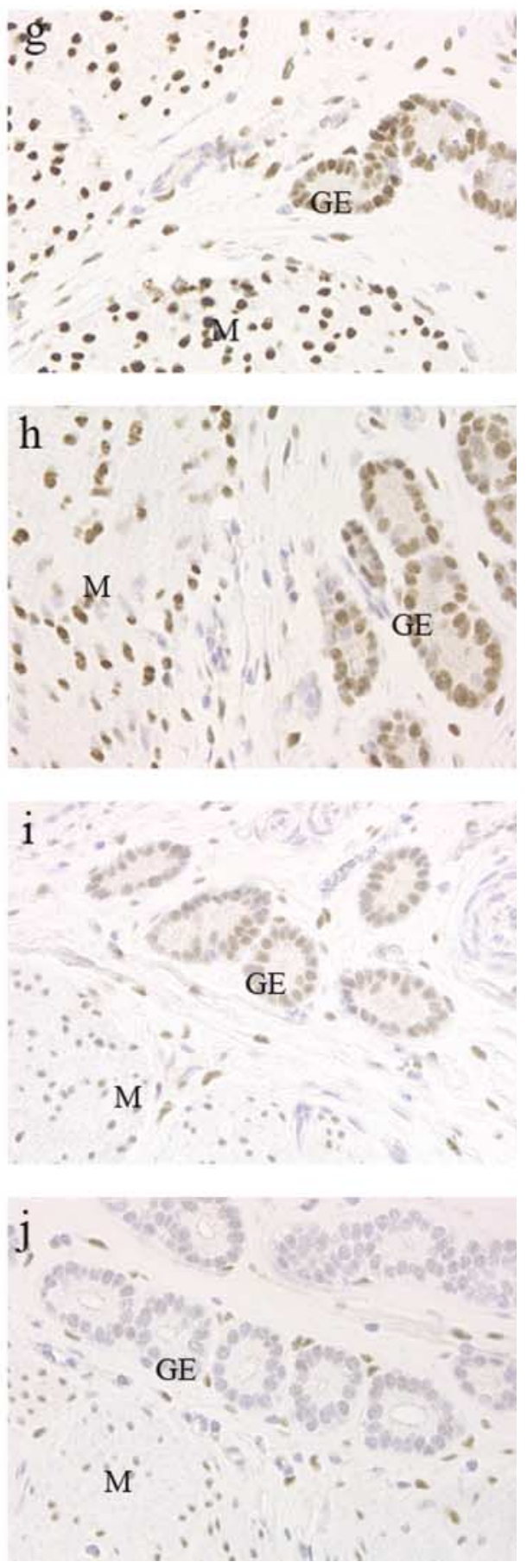

Figure 3 Immunohistochemical localization of PR in different tissue compartments of the sow uterus: $\mathrm{a}-\mathrm{e}$, surface epithelium (SE) and subepithelial layer of connective tissue (STR); $\mathrm{f}-\mathrm{j}$, glandular epithelium (GE) and myometrium (M). Stages of pregnancy: group 1 , $5-6 \mathrm{~h}$ after $\mathrm{Al}$ (a and f); group 2, $20-25 \mathrm{~h}$ after ovulation (b and g); group 3, $70 \mathrm{~h}$ after ovulation (c and h); group 4, d 11 after standing oestrous (d and i); group 5, d 19 after standing oestrous (e and $\mathrm{j}$ ). 
Table 1 Immunohistochemical staining of progesterone receptor (PR) presented as manual scoring (intensity and proportion) and as ratios of positive nuclei by image analysis unit results (mean \pm S.D.) in different uterine tissue compartments of non-pregnant sows at different stages of the oestrous cycle.

\begin{tabular}{|c|c|c|c|c|c|}
\hline Stage of the oestrus cycle & Surface epithelium & $\begin{array}{l}\text { Glandular epithelium } \\
\text { (superficial glands) }\end{array}$ & $\begin{array}{l}\text { Glandular epithelium } \\
\text { (deep glands) }\end{array}$ & $\begin{array}{c}\text { Connective tissue stroma } \\
\text { (subepithelial layers) }\end{array}$ & Myometrium \\
\hline $\begin{array}{l}\text { Pro-oestrus (d 19)* } \\
\text { Oestrus }(\mathrm{d} 1)^{*} \\
\text { Early dioestrus (d 4)* } \\
\text { Dioestrus (d 10-11)* } \\
\text { Late dioestrus (d 17)* } \\
\text { Overall significant }\end{array}$ & $\begin{array}{c}-/+\mathrm{A}\left(0.18 \pm 0.2^{\mathrm{b}}\right) \\
++/+++\mathrm{D}\left(50.37 \pm 28.7^{\mathrm{a}}\right) \\
++/+++\mathrm{D}\left(67.85 \pm 19.1^{\mathrm{a}}\right) \\
-/+\mathrm{A}\left(0.04 \pm 0.1^{\mathrm{b}}\right) \\
-/+\mathrm{A}\left(0.02 \pm 0.02^{\mathrm{b}}\right) \\
P<0.001\end{array}$ & $\begin{array}{l}+\mathrm{A}\left(7.16 \pm 6.7^{\mathrm{a}}\right) \\
+/++\mathrm{B}\left(12.30 \pm 8.7^{\mathrm{b}}\right) \\
++\mathrm{D}\left(2.28 \pm 3.1^{\mathrm{ad}}\right) \\
+\mathrm{D}\left(0 \pm 0.00^{\mathrm{c}}\right) \\
+\mathrm{D}\left(0.60 \pm 0.8^{\mathrm{d}}\right) \\
\quad P<0.001\end{array}$ & $\begin{array}{c}+/++\mathrm{D}\left(16.9 \pm 14.4^{\mathrm{a}}\right) \\
++/+++\mathrm{D}\left(62.59 \pm 31.6^{\mathrm{b}}\right) \\
+/++\mathrm{D}\left(0.67 \pm 1.1^{\mathrm{c}}\right) \\
++\mathrm{D}\left(14.51 \pm 24.6^{\mathrm{c}}\right) \\
+/++\mathrm{D}\left(0.27 \pm 0.46^{\mathrm{c}}\right) \\
P<0.001\end{array}$ & $\begin{array}{c}++/+++\mathrm{D}\left(46.14 \pm 11.3^{\mathrm{a}}\right) \\
+++\mathrm{D}\left(66.54 \pm 6.7^{\mathrm{b}}\right) \\
++/+++\mathrm{D}\left(50.03 \pm 10.9^{\mathrm{a}}\right) \\
++\mathrm{D}\left(22.81 \pm 23.3^{\mathrm{c}}\right) \\
++\mathrm{D}\left(38.03 \pm 11.54^{\mathrm{d}}\right) \\
P<0.001\end{array}$ & $\begin{array}{c}++/+++\mathrm{D}\left(50.09+23.1^{\mathrm{a}}\right) \\
++/+++\mathrm{D}\left(59.16 \pm 3.2^{\mathrm{a}}\right) \\
+/++\mathrm{D}\left(8.3 \pm 3.6^{\mathrm{b}}\right) \\
+/++\mathrm{D}\left(0.45 \pm 0.7^{\mathrm{c}}\right) \\
+/++\mathrm{D}\left(1.60 \pm 2.27^{\mathrm{c}}\right) \\
\quad P<0.001\end{array}$ \\
\hline
\end{tabular}

Staining intensity: - , negative; + , weak; ++ , moderate; +++ , strong.

A, low proportion $(<30 \%)$; B, moderate proportion $(30-60 \%)$; C, high proportion ( $>60-90 \%)$; D, almost all cells $(>90 \%)$ are positive.

* day 1 , first day of standing oestrus.

The different superscript letters are significantly different $(P<0.05)$

Table 2 Immunohistochemical staining of progesterone receptor (PR) presented as manual scoring (intensity and proportion) and as ratios of positive nuclei by image analysis unit results (mean \pm S.D.) in different uterine tissue compartments of inseminated sows at oestrus and early pregnancy.

\begin{tabular}{|c|c|c|c|c|c|}
\hline Group of pregnant sows & Surface epithelium & $\begin{array}{l}\text { Glandular epithelium } \\
\text { (superficial glands) }\end{array}$ & $\begin{array}{l}\text { Glandular epithelium } \\
\text { (deep glands) }\end{array}$ & $\begin{array}{l}\text { Connective tissue } \\
\text { (subepithelial layers) }\end{array}$ & Myometrium \\
\hline $\begin{array}{l}\text { Group } 1 \text { (oestrus, } 5-6 \mathrm{~h} \text { after } \mathrm{Al}) \\
\text { Group } 2 \text { (20-25 h after ovulation) } \\
\text { Group } 3 \text { ( } 70 \mathrm{~h} \text { after ovulation) } \\
\text { Group } 4(\mathrm{~d} 11)^{*} \\
\text { Group } 5 \text { (d 19)* } \\
\text { Overall significant }\end{array}$ & $\begin{array}{c}+/++\mathrm{D}\left(33.14 \pm 8.14^{\mathrm{a}}\right) \\
+/++\mathrm{D}\left(19.84 \pm 18.01^{\mathrm{b}}\right) \\
++/+++\mathrm{D}\left(49.71 \pm 19.32^{\mathrm{a}}\right) \\
-/+\mathrm{A}\left(12.58 \pm 24.75^{\mathrm{c}}\right) \\
-/+\mathrm{A}\left(3.27 \pm 6.20^{\mathrm{C}}\right) \\
P<0.001\end{array}$ & $\begin{array}{l}+/++\mathrm{D}\left(19.07 \pm 12.6^{\mathrm{a}}\right) \\
+\mathrm{D}\left(6.22 \pm 6.6^{\mathrm{b}}\right) \\
++\mathrm{D}\left(7.10 \pm 12.1^{\mathrm{b}}\right) \\
+/++\mathrm{D}\left(4.24 \pm 3.5^{\mathrm{b}}\right) \\
+\quad \mathrm{D}\left(1.14 \pm 2.07^{\mathrm{c}}\right) \\
\quad P<0.001\end{array}$ & $\begin{array}{c}++/+++\mathrm{D}\left(87.75 \pm 7.0^{\mathrm{a}}\right) \\
++/+++\mathrm{D}\left(44.9 \pm 28.2^{\mathrm{b}}\right) \\
++\mathrm{D}\left(10.7 \pm 18.4^{\mathrm{c}}\right) \\
+/++\mathrm{D}\left(6.16 \pm 5.04^{\mathrm{c}}\right) \\
+\mathrm{D}\left(1.88 \pm 2.9^{\mathrm{d}}\right) \\
\quad P<0.001\end{array}$ & $\begin{array}{c}++/+++\mathrm{D}\left(60.24 \pm 3.8^{\mathrm{a}}\right) \\
++/+++\mathrm{D}\left(34.97 \pm 10.8^{\mathrm{b}}\right) \\
++\mathrm{D}\left(31.2 \pm 13.1^{\mathrm{b}}\right) \\
+/++\mathrm{D}\left(32.8 \pm 13.0^{\mathrm{b}}\right) \\
++\mathrm{D}\left(26.01 \pm 8.4^{\mathrm{b}}\right) \\
P<0.001\end{array}$ & $\begin{array}{c}++/+++\mathrm{D}\left(46.7+20.1^{\mathrm{a}}\right) \\
++/+++\mathrm{D}\left(36.11 \pm 16.4^{\mathrm{a}}\right) \\
+/++\mathrm{D}\left(7.59 \pm 11.6^{\mathrm{b}}\right) \\
+\mathrm{D}\left(3.44 \pm 3.43^{\mathrm{b}}\right) \\
+\mathrm{D}\left(1.9 \pm 1.4^{\mathrm{b}}\right) \\
P<0.01\end{array}$ \\
\hline
\end{tabular}

Staining intensity: - , negative; + , weak; ++ , moderate; +++ , strong.

A, low proportion $(<30 \%)$; B, moderate proportion (30-60\%); C, high proportion ( $>60-90 \%)$; D, almost all cells $(>90 \%)$ are positive.

* day 1 , first day of standing oestrus.

$\vec{N} \quad$ The different superscript letters are significantly different $(P<0.05)$ 
ovulation (groups 1 and 2) whereas weak staining was found at $d 11$ and $d 19$ (groups 4 and 5). The mean ratios of PR-positive cells from image analysis at oestrus and 20-25 h after ovulation (groups 1 and 2) were significantly higher than at the other stages of early pregnancy (groups 3-5) $(P<0.01)$.

\section{Results on correlation between image analysis results and plasma hormone levels}

\section{Non-pregnant cyclic sows (experiment A)}

In cyclic sows, significantly positive correlations between PR-immunolabelling and plasma levels of oestradiol-17 $\beta$ were found for the glandular epithelium (both superficial and deep glands) $(P<0.001)$, the connective tissue $(P<0.001)$ and the myometrium $(P<0.001)$. Negative correlations between PR-positive cells and the plasma levels of progesterone were observed in the same compartments $(P<0.001)$.

\section{Inseminated/early pregnant sows (experiment B)}

Significant positive correlations were found between plasma oestradiol-17 $\beta$ levels and PR-positive cells in the uterus of inseminated/early pregnant sows in the superficial and deep glands $(P<0.001)$, connective tissue $(P<0.001)$ and myometrium $(P<0.001)$. The plasma progesterone levels were negatively correlated with PR-immunolabelling in all of the tissue compartments studied except the surface epithelium i.e. the superficial and the deep glands $(P<0.001)$, the connective tissue $(P<0.001)$ and the myometrium $(P<0.001)$.

\section{Discussion}

The localization of progesterone receptors (PR) was investigated in the uteri of cyclic and inseminated/early pregnant sows by using a mouse monoclonal antibody which recognizes an epitope present in both isoforms of the receptor (PR-A and PR-B). Both isoforms have been shown by western blot to be present in the porcine ovary (Slomczynska et al. 2000) and uterus (Geisert et al. 1994). The isoforms only differ with respect to an aminoterminal extension on PR-B (Gronemeyer et al. 1991). However, it has been suggested that the PR-A and PR-B proteins have different conformations (Mote et al. 2000) as there are differences in immunohistochemical binding patterns to cell clones specific to their respective isoform even if an antibody has been shown by western blot to detect both isoforms.

In the present study, immunostaining was evaluated by two different methods, a manual scoring and image analysis. The results from the manual scoring showed variations in patterns of PR-immunostaining with regard to both proportion and intensity while the image analysis quantified the total amount of clearly positive staining (moderate to strong) in randomly selected areas. When comparing the two methods, the results for most compartments were in agreement with each other. However, differences were observed at some stages/groups and one explanation could be the difference regarding weak staining intensity which was estimated manually but excluded from the image analysis measurement as described above. Another explanation could be that the manual scoring method evaluated the whole tissue while the image analysis was limited to five randomly selected areas.

The present study showed that the level of PR-immunostaining was high in most compartments of the uterus at oestrus in cyclic sows (experiment A) as well as in newly inseminated sows (groups 1 and 2, experiment. B) which is in accordance with other studies on PR in pigs (Koziorowski et al. 1984, Kotwica 1986, Stanchev et al. 1990, Geisert et al. 1994). Studies in different species (Dhaliwal et al. 1997, Ing \& Tornesi 1997, Bouchard 1999) have described that oestrogen upregulates the progesterone receptor whereas progesterone downregulates both oestrogen receptors and its own receptors but these effects are time- and tissue-specific. Both methods used in the present study support these earlier results on PR as the immunopresence in the glandular epithelium, connective tissue and myometrium of cyclic sows in most cases was high when plasma levels of oestradiol- $17 \beta$ were high and low when progesterone levels were high. In addition, positive correlations with plasma oestradiol- $17 \beta$ were found for these compartments in cyclic sows. Negative correlations were found between plasma levels of progesterone and PR-immunostaining in most tissue compartments of both cyclic and inseminated/early pregnant sows. However, in some compartments, such as the surface epithelium of sows from both experiments, positive PR cells did not correlate with the plasma oestradiol- $17 \beta$ in the present study. Thus, our results show that the mechanisms of PR upregulation by oestradiol- $17 \beta$ in plasma vary in different uterine tissue compartments and that some other factors or regulatory mechanisms should be involved. Supporting this, our recent findings in anoestrous sows (Sukjumlong et al. 2004a) that have low levels of plasma steroid hormones, showed strong staining of PR in all compartments of the uterus except the glandular epithelium.

In the surface epithelium, low intensity and low proportion of PR immunopositive cells were found at prooestrus even though the plasma level of oestradiol-17 $\beta$ was high. At oestrus as well as early dioestrus $/ 70 \mathrm{~h}$ after ovulation, the levels of PR were significantly increased. However, in inseminated sows, a significantly lower mean ratio of PR-positive cells was observed at 20-25 h after ovulation. For the non-inseminated sows, a stage comparable to 20-25 h after ovulation was not studied, thus it was not clear whether this temporary downregulation of PR in the surface epithelium was caused by insemination or only by the lower plasma level of oestradiol-17 $\beta$ compared with at oestrus. As PR is generally upregulated by oestrogens, the lack of high PR levels in the surface epithelium at prooestrus indicates a delayed effect, possibly 
via ER $\alpha$ in the stroma as will be discussed below. This is supported by our previous studies (Sukjumlong et al. 2003, 2004b) showing that stromal ER $\alpha$ was high at prooestrus. At later stages (dioestrus, and late dioestrus/d 11 and $d$ 19), the PR levels in the surface epithelium of the present study were low. It has been shown that the morphology of luminal epithelial secretory cells did not differ between cyclic and pregnant gilts up to d10 (Stroband et al. 1986). Our present study supports the lack of difference between cyclic and inseminated animals as the pattern of PR presence in the surface epithelium was similar at comparable stages.

Geisert et al. (1994) studied PR in the gilt uterus by different methods including immunocytochemistry. Their results showed that PR could not be detected in the surface and glandular epithelia on d 12-18 of the oestrous cycle and early pregnancy but was still present in the stroma and myometrium. Our results differed slightly from this by showing that PR was detected in the epithelia at all stages/groups though it was very low at some stages of the oestrous cycle and pregnancy. It was suggested by another study on porcine cultured endometrial cells (Carnahan et al. 2002) that PR may be present in the endometrial epithelium at a lower level than the sensitivity of immunohistochemistry can detect but still permit the response to progesterone. This, and other methodological variations such as sampling time, fixation and type of antibody, could explain the differences in results. Another explanation may be differences in uterine physiology between gilts and sows regarding the presence of PR although that can not be proven by the present study as no gilts were included and differences to the results on gilts by Geisert et al. (1994) are not apparent.

Surface and glandular epithelia should be considered as two functionally different cell populations as the pattern of synthesis and release of their products were shown to be different (Fazleabas et al. 1985). As progesterone is involved in secretory functions in the uterus (Adams et al. 1981, Roberts et al. 1987, Vallet et al. 1998), differences in PR immunopresence could therefore be expected. Our results support this concept by showing PR differences between surface and glandular compartments. The glandular epithelium can be further divided into functional units as the present study showed that the levels of PRpositive cells differed between superficial and deep layers which is in agreement with other PR studies in ewes (Spencer \& Bazer 1995) and bitches (Vermeirsch et al. 2000) as well as our earlier studies on ER $\alpha$ using the same sows. (Sukjumlong et al. 2003, 2004b). This indicates different roles or functions for glandular levels under the same steroid hormone regulation. In the present study, PR ratios from image analyses were higher in the glandular epithelium of inseminated sows at 5-6 h after $\mathrm{Al}$ than in non-inseminated sows at oestrus which might be an effect by insemination. As the semen from boars contains high levels of oestrogen (Claus et al. 1987) it could act locally on the endometrium in addition to plasma oestradiol-17 $\beta$ and result in the upregulation of glandular PR.

In comparison with our previous study on ER $\alpha$ using the same cyclic (Sukjumlong et al. 2003) and inseminated/early pregnant sows (Sukjumlong et al. 2004b), some differences could be observed between ER $\alpha$ and PR immunostaining. In the glandular epithelium of cyclic sows, PR staining intensity was higher at oestrus than at early dioestrus while $E R \alpha$ staining intensity was vice versa. Furthermore, in the surface epithelium of inseminated/early pregnant sows, high presence of PR (intensity and proportion) was observed at oestrus and at $70 \mathrm{~h}$ after ovulation (groups 1 and 3) whereas ER $\alpha$ intensity and proportion was low in those groups (Sukjumlong et al. 2004b). This shows that the high level of PR presence occurred before $E R \alpha$ in the uterine glands which indicates that the appearance of ER $\alpha$ and PR in the epithelia are differently regulated at the same reproductive stage.

Studies in the mouse have demonstrated that expression of epithelial PR requires the presence of PR in the stroma (Kurita et al. 2000a,b, 2001). Moreover, it has been reported in primates that uterine epithelia were more sensitive to downregulation by progesterone than stromal cells (Lessey et al. 1988, Brenner et al. 1990, Hild-Petito et al. 1992). Similarly, in pregnant women and ewes, endometrial stroma remained PR-positive throughout pregnancy while the epithelial PR was downregulated which indicated that the actions of progesterone on endometrial epithelia at gestation might be mediated by the stroma (Perrot-Applanat et al. 1994, Spencer \& Bazer 2002). The results of the present study support these concepts of stromal PR by showing (after oestrus) that the presence of PR positive cells was maintained in the connective tissue during the oestrous cycle as well as in inseminated/early pregnant sows.

In the sow myometrium, uterine contractions have been shown to increase around oestrus (Scheerboom et al. 1987, Langendijk et al. 2002). In the myometrium at oestrus we found high levels of ER $\alpha$ in both cyclic and inseminated sows in our previous studies (Sukjumlong et al. 2003, 2004b) and high levels of PR in both experimental groups of sows in the present study. Furthermore, Scheerboom et al. (1987), reported that the characteristics of uterine myometrial activity during pregnancy were similar to those of a cyclic sow until day 12, and were thereby independent of the presence of blastocysts. Our present study supports this finding by showing a similar decrease of $\mathrm{PR}$ in the myometrium from oestrus until late dioestrus in cyclic sows/d 19 in early pregnant sows. From these results, we speculate that PR in the myometrium is upregulated by high plasma levels of oestradiol-17 $\beta$ during oestrus in order to prepare for the progesterone regulation via PR at following stages of the oestrous cycle/pregnancy. Increasing and high levels of progesterone have been shown to provide a quiescent uterus with low myometrial activity (Porter \& Watts 1986, Ding et al. 1994) and to decrease PR levels (Batra \& losif 1989, Bouchard 1999), 
which was supported by our present results with low PR levels at d 19 of early pregnant sows (group 5, experiment B) compared with high PR levels at prooestrus in cyclic sows (experiment A).

From the previous studies of ER $\alpha$ and proliferative activities in the uteri of the same sows (Sukjumlong et al. 2003, 2004b), significant correlation was found between $\mathrm{ER} \alpha$ stromal cells and a proliferative marker, $\mathrm{Ki}-67$, in the epithelia. Though no significant correlation between ER $\alpha$ and $\mathrm{Ki}-67$ cells was found for the other tissue compartments, a similar pattern was noticed. However, there may be other factors than oestrogen involved in the regulation of proliferation as progesterone has also been shown to promote proliferation via the induction of growth factors (Reynolds et al. 1990, Taketani \& Mizuno 1991) and a high correlation between PR expression and endometrial cell proliferation was found in early pregnant goats (Flores et al. 2001). In addition, downregulation of PR resulted in inhibition of uterine stromal cell proliferation in pregnant rats (Rider \& Psychoyos 1994). In the present study, a high presence of PR in the epithelia was observed at oestrus, while high proliferation, as studied previously (Sukjumlong et al. 2003, 2004b), was observed in the glandular epithelium at early dioestrus/70 h after ovulation in cyclic and early pregnant sows respectively. It is therefore suggested that high proliferation in the glandular epithelium may be due to the high presence of PR at oestrus, being occupied by low but increasing levels of progesterone and resulting in an induction of proliferation at following stages. An alternative is that proliferation is stimulated indirectly via receptors in the stroma and by growth factors. However, the mechanisms of this regulation need to be elucidated by further studies.

In conclusion, this study shows that immunopresence of PR in the sow uterus differed between uterine compartments at the same reproductive stage. Differences were also found for some uterine compartments when comparing cyclic and inseminated/early pregnant sows at corresponding stages. The relatively consistent immunostaining of PR in the stroma of both cyclic and inseminated/early pregnant sows strengthens a stromal role in the regulation of physiological activities in the sow uterus during the oestrous cycle as well as early pregnancy.

\section{Acknowledgement}

We are grateful to Britt Masironi, Department of Woman and Child Health, Karolinska Institutet, Stockholm, Sweden for her kind help with the image analysis system. Kampon Kaeoket is acknowledged for all his work on the clinical parts and sample collection. The authors also wish to thank Nils Lundeheim, Department of Animal Breeding and Genetics for advice in statistical analysis. The present study received financial support from the Swedish Foundation for International Cooperation in Research and Higher Education (STINT) and research funds from Swedish Meats and the Swedish Swine Research foundation.

\section{References}

Adams KL, Bazer FW \& Roberts RM 1981 Progesterone-induced secretion of a retinol-binding protein in the pig uterus. Journal of Reproduction and Fertility 62 39-47.

Batra S \& Iosif CS 1989 Tissue specific effects of progesterone on progesterone and estrogen receptors in the female urogenital tract. Journal of Steroid Biochemistry and Molecular Biology 32 35-39.

Bouchard P 1999 Progesterone and the progesterone receptor. Journal of Reproductive Medicine 44 153-157.

Brenner RM, West NB \& McClellan MC 1990 Estrogen and progestin receptors in the reproductive tract of male and female primates. Biology of Reproduction 42 11-19.

Carnahan KG, Uzumcu M, Hu J, Sample GL, Braileanu GT \& Mirando MA 2002 Oxytocin stimulates secretion of prostaglandin $F_{2 \alpha}$ from endometrial cells of swine in the presence of progesterone. Domestic Animal Endocrinology 23 435-445.

Claus R, Hoang-Vu C, Ellendorff F, Meyer HD, Schopper D \& Weiler U 1987 Seminal oestrogens in the boar: origin and functions in the sow. Journal of Steroid Biochemistry and Molecular Biology 27 331-335.

Conneely OM, Mulac-Jericevic B, Lydon JP \& De Mayo FJ 2001 Reproductive functions of the progesterone receptor isoforms: lessons from knock-out mice. Molecular and Cellular Endocrinology 179 97-103.

Dhaliwal GK, England GC \& Noakes DE 1997 Immunocytochemical localization of oestrogen and progesterone receptors in the uterus of the normal bitch during oestrus and metoestrus. Journal of Reproduction and Fertility 51 (Suppl) 167-176.

Ding YQ, Zhu LJ, Bagchi MK \& Bagchi IC 1994 Progesterone stimulates calcitonin gene expression in the uterus during implantation. Endocrinology 135 2265-2274.

Fazleabas AT, Bazer FW, Hansen PJ, Geisert RD \& Roberts RM 1985 Differential patterns of secretory protein localization within the pig uterine endometrium. Endocrinology 116 240-245.

Flores JM, Sanchez MA, Nieto A, Sanchez B, Gonzalez M \& Garcia P 2001 Detection of estrogen alpha and progesterone receptors and cell proliferation in the uterus during early pregnancy in the goat. Theriogenology 56 341-355.

Geisert RD, Pratt TN, Bazer FW, Mayes JS \& Watson GH 1994 Immunocytochemical localization and changes in endometrial progestin receptor protein during the porcine oestrous cycle and early pregnancy. Reproduction, Fertility, and Development 6 749-760.

Graham JD \& Clarke CL 1997 Physiological action of progesterone in target tissues. Endocrine Reviews 18 502-519.

Gronemeyer H, Meyer ME, Bocquel MT, Kastner P, Turcotte B \& Chambon P 1991 Progestin receptors: isoforms and antihormone action. Journal of Steroid Biochemistry and Molecular Biology $\mathbf{4 0}$ 271-278.

Hild-Petito S, Verhage HG \& Fazleabas AT 1992 Immunocytochemical localization of estrogen and progestin receptors in the baboon (Papio anubis) uterus during implantation and pregnancy. Endocrinology $1302343-2353$.

Ing NH \& Tornesi MB 1997 Estradiol up-regulates estrogen receptor and progesterone receptor gene expression in specific ovine uterine cells. Biology of Reproduction 56 1205-1215.

Kaeoket K, Persson E \& Dalin AM 2001 The sow endometrium at different stages of the oestrous cycle: studies on morphological changes and infiltration by cells of the immune system. Animal Reproduction Science 65 95-114.

Kaeoket K, Persson E \& Dalin AM 2002 The influence of pre- and post-ovulatory insemination on sperm distribution in the oviduct, accessory sperm to the zona pellucida, fertilisation rate and embryo development in sows. Anim Reprod Sci 71 239-248.

Kotwica G 1986 Progesterone level in the peripheral blood and the cytosol progesterone receptor in the uterine mucosa and myometrium of sows during the estrous cycle. Polskie Archiwum Wetergnaryjne 25 77-89. 
Koziorowski M, Kotwica G, Stefanczyk S \& Krzymowski T 1984 Estradiol, progesterone and testosterone receptors for pig endometrium and myometrium at various stages of the estrous cycle. Experimental Clinical Endocrinology 84 285-293.

Kurita T, Lee KJ, Cooke PS, Lydon JP \& Cunha GR 2000a Paracrine regulation of epithelial progesterone receptor and lactoferrin by progesterone in the mouse uterus. Biology of Reproduction 62 831-838.

Kurita T, Lee KJ, Cooke PS, Taylor JA, Lubahn DB \& Cunha GR $2000 b$ Paracrine regulation of epithelial progesterone receptor by estradiol in the mouse female reproductive tract. Biology of Reproduction 62 821-830.

Kurita T, Wang YZ, Donjacour AA, Zhao C, Lydon JP, O'Malley BW, Isaacs JT, Dahiya R \& Cunha GR 2001 Paracrine regulation of apoptosis by steroid hormones in the male and female reproductive system. Cell Death Differentiation 8 192-200.

Langendijk P, Bouwman EG, Soede NM, Taverne MA \& Kemp B 2002 Myometrial activity around estrus in sows: spontaneous activity and effects of estrogens, cloprostenol, seminal plasma and clenbuterol. Theriogenology 57 1563-1577.

Lessey BA, Killam AP, Metzger DA, Haney AF, Greene GL \& McCarty KS Jr 1988 Immunohistochemical analysis of human uterine estrogen and progesterone receptors throughout the menstrual cycle. Journal of Clinical Endocrinology and Metabolism 67 334-340.

Lydon JP, DeMayo FJ, Conneely OM \& O'Malley BW 1996 Reproductive phenotpes of the progesterone receptor null mutant mouse. Journal of Steroid Biochemistry and Molecular Biology $\mathbf{5 6}$ $67-77$.

Mote PA, Balleine RL, McGowan EM \& Clarke CL 2000 Heterogeneity of progesterone receptors $\mathrm{A}$ and $\mathrm{B}$ expression in human endometrial glands and stroma. Human Reproduction 15 (Suppl 3) $48-56$.

Mwanza AM, Madej A, Kindahl H, Lundeheim N \& Einarsson S 2000 Plasma levels of cortisol, progesterone, oestradiol-17 beta and prostaglandin F2 alpha metabolite after ACTH (Synacthen Depot) administration in ovariectomized gilts. Journal of Veterinary Medicine A; Physiology, Pathology, Clinical Medicine 47 193-200.

Ohta Y, Sato T \& Iguchi T 1993 Immunocytochemical localization of progesterone receptor in the reproductive tract of adult female rats. Biology of Reproduction 48 205-213.

Perrot-Applanat M, Deng M, Fernandez H, Lelaidier C, Meduri G \& Bouchard P 1994 Immunohistochemical localization of estradiol and progesterone receptors in human uterus throughout pregnancy: expression in endometrial blood vessels. Journal of Clinical Endocrinology and Metabolism 78 216-224.

Persson E, Sahlin L, Masironi B, Dantzer V, Eriksson H \& RodriguezMartinez H 1997 Insulin-like growth factor-I in the porcine endometrium and placenta: localization and concentration in relation to steroid influence during early pregnancy. Animal Reproduction Science 46 261-281.

Porter DG \& Watts AD 1986 Relaxin and progesterone are myometrial inhibitors in the ovariectomized non-pregnant mini-pig. Journal of Reproduction and Fertility 76 205-213.

Pursel VG \& Johnson LA 1976 Frozen boar spermatozoa: methods of thawing pellets. Journal of Animal Science 42 927-931.

Reynolds RK, Talavera F, Roberts JA, Hopkins MP \& Menon KM 1990 Regulation of epidermal growth factor and insulin-like growth factor I receptors by estradiol and progesterone in normal and neoplastic endometrial cell cultures. Gynecology and Oncology 38 396-406.

Rider V \& Psychoyos A 1994 Inhibition of progesterone receptor function results in loss of basic fibroblast growth factor expression and stromal cell proliferation during uterine remodelling in the pregnant rat. Journal of Endocrinology 140 239-249.
Roberts RM, Murray MK, Burke MG, Ketcham CM \& Bazer FW 1987 Hormonal control and function of secretory proteins. Advances in Experimental Medicine and Biology 230 137-150.

Rojkittikhun T, Einarsson S, Zilinskas H, Edqvist LE, Uvnas-Moberg $\mathrm{K}$ \& Lundeheim N 1993 Effects of insulin administration at weaning on hormonal patterns and reproductive performance in primiparous sows. Zentralb/ Veterinarmed A 40 161-168.

Scheerboom JE, Van Adrichem PW \& Taverne MA 1987 Uterine motility of the sow during the oestrous cycle and early pregnancy. Verterinarg Research Communications 11 253-269.

Simonsson A 1994 Naringsrekommendationer och fodermedel till svin, Swedish University of Agricultural Sciences.

Slomczynska M, Krok M \& Pierscinski A 2000 Localization of the progesterone receptor in the porcine ovary. Acta Histochemica $102183-191$.

Spencer TE \& Bazer FW 1995 Temporal and spatial alterations in uterine estrogen receptor and progesterone receptor gene expression during the estrous cycle and early pregnancy in the ewe. Biology of Reproduction 53 1527-1543.

Spencer TE \& Bazer FW 2002 Biology of progesterone action during pregnancy recognition and maintenance of pregnancy. Frontiers in Bioscience 7 d1879-d1898.

Spencer TE, Johnson GA, Burghardt RC \& Bazer FW 2004 Progesterone and placental hormone actions on the uterus: insights from domestic animals. Biology of Reproduction 71 2-10.

Stanchev P, Rodriguez-Martinez H, Edqvist LE \& Eriksson H 1990 Characterization of uterine sex steroid receptors in the pig and their variation during the oestrous cycle. Journal of Steroid Biochemistry and Molecular Biology 35 689-699.

Stroband HW, Taverne N, Langenfeld K \& Barends PM 1986 The ultrastructure of the uterine epithelium of the pig during the estrous cycle and early pregnancy. Cell and Tissue Research 246 $81-89$.

Sukjumlong S, Dalin AM \& Persson E 2004a Immunohistochemical localization of oestrogen receptor alpha $(E R \alpha)$, progesterone receptors (PR) and the proliferative marker Ki-67, in the uterus of newly weaned anoestrous sows. 15th International Congress on Animal Reproduction, Porto Seguro, Brazil.

Sukjumlong S, Kaeoket K, Dalin AM \& Persson E 2003 Immunohistochemical studies on oestrogen receptor alpha (ER $\alpha)$ and the proliferative marker $\mathrm{Ki}-67$ in the sow uterus at different stages of the oestrous cycle. Reproduction in Domestic Animals 38 5-12.

Sukjumlong S, Persson E, Kaeoket K \& Dalin AM 2004b Immunohistochemical studies on oestrogen receptor alpha (ERalpha) and the proliferative marker $\mathrm{Ki}-67$ in the sow uterus at oestrus and early pregnancy. Reproduction in Domestic Animals 39 361-369.

Taketani Y \& Mizuno M 1991 Evidence for direct regulation of epidermal growth factor receptors by steroid hormones in human endometrial cells. Human Reproduction 6 1365-1369.

Vallet JL, Christenson RK, Trout WE \& Klemcke HG 1998 Conceptus, progesterone, and breed effects on uterine protein secretion in swine. Journal of Animal Science 76 2657-2670.

Vermeirsch H, Simoens P \& Lauwers H 2000 Immunohistochemical detection of the estrogen receptor-alpha and progesterone receptor in the canine pregnant uterus and placental labyrinth. Anatomical Record $26042-50$.

Wathes DC \& Hamon M 1993 Localization of oestradiol, progesterone and oxytocin receptors in the uterus during the oestrous cycle and early pregnancy of the ewe. Journal of Endocrinology 138 479-492.

Received 7 October 2004

First decision 19 October 2004

Revised manuscript received 30 November 2004

Accepted 8 December 2004 